\title{
THE EFFECT OF BURNOUT SYNDROME ON TURNOVER INTENTION USING ORGANIZATIONAL COMMITMENT AS AN INTERMEDIATE VARIABLE
}

\author{
Pengaruh Burnout Syndrome Terhadap Turnover Intention dengan \\ Komitmen Organisasi Sebagai Variabel Perantara
}

\author{
'Maya Weka Santi ${ }^{1}$, Nurhasmadiar Nandini ${ }^{2}$, Gamasiano Alfiansyah ${ }^{1}$ \\ ${ }^{1}$ Health Department, Politeknik Negeri Jember, Indonesia \\ ${ }^{2}$ Faculty of Public Health, Diponegoro University, Semarang, Indonesia \\ ${ }^{*}$ Correspondence: mayaweka@polije.ac.id
}

\begin{abstract}
Background: The average of employee turnover rate in Surabaya Surgical Hospital was quite high roughly about $16.21 \%$ in 2011 until 2015. Employees' negative behavior or feelings due to long exposure to an emotional stressor are called burnout syndrome which could trigger turnover in an organization.

Aims: This study analyzed the effect of burnout syndrome towards turnover intention using organizational commitment as an intermediate variable.

Methods: This study was cross-sectional research by involving 126 respondents as samples according to the proportion of each unit at Surabaya Surgical Hospital. Data were analysed statistically using multiple linier regression.

Results: Respondents were mostly female (65.1\%) and in the age group of $26-35$ years (62.7\%). Most of them were early adults, permanent employees $(95.2 \%)$, and undergraduates $(89.7 \%)$. While the minority have worked for 3 up to 4 years (40.5\%). Burnout syndrome had a significant effect on employees' organizational commitment. Organizational commitment showed a significant effect on turnover intention, while burnout syndrome did not show a significant effect on turnover intention.

Conclusion: Burnout syndrome did not directly affect turnover intention but became a possible cause of turnover intention through organizational commitment as the intermediate variable. The results of this study could be the basis for hospital managers to decrease employee's turnover intention by minimizing burnout syndrome and increasing organizational commitment with a better reward system.
\end{abstract}

Keywords: burnout syndrome, organizational commitment, turnover intention, hospital.

\section{ABSTRAK}

Latar Belakang: Rata-rata tingkat turnover karyawan di Rumah Sakit Bedah Surabaya cukup tinggi, kurang lebih $16,21 \%$ pada 2011 hingga 2015. Perilaku atau perasaan negatif karyawan karena paparan yang lama kepada stesor emosional sering dikenal sebagai burnout syndrome yang dapat memicu turnover di sebuah organisasi.

Tujuan: Penelitian ini bertujuan untuk melakukan analisis pengaruh burnout syndrome terhadap turnover intention melalui komitmen organisasi sebagai variabel perantara.

Metode: Jenis penelitian ini adalah cross sectional dengan melibatkan 126 responden sesuai proporsi masingmasing unit dalam rumah sakit. Data dianalisis secara statistik menggunakan regresi linier berganda.

Hasil: Sebagian besar responden adalah perempuan $(65,1 \%)$ dan berada pada kelompok umur 26-35 tahun (62,7\%). Sebagian besar adalah dewasa muda, karyawan tetap (95,2\%), dan sarjana (89,7\%). Sedangkan, sebagian kecil dari mereka telah bekerja 3 sampai 4 tahun (40,5\%). Burnout syndrome berpengaruh secara signifikan terhadap komitmen organisasi karyawan. Komitmen organisasi memiliki pengaruh secara signifikan terhadap turnover intention, sedangkan burnout syndrome tidak memiliki pengaruh signifikan terhadap turnover intention

Kesimpulan: Burnout syndrome tidak berpengaruh secara langsung terhadap turnover intention, tetapi mungkin dapat menjadi penyebab turnover intention melalui komitmen organisasi sebagai variabel perantara. Berdasarkan hasil penelitian, kepala rumah sakit dapat melakukan upaya untuk menurunkan turnover intention dengan meminimalisir burnout syndrome dan meningkatkan komitmen organisasi dengan sistem reward yang lebih baik.

Kata kunci: burnout syndrome, komitmen organisasi, turnover intention, rumah sakit. 


\section{INTRODUCTION}

Healthcare service organizations have several characteristics, such as intangible outputs, service inseparability, and labor intensiveness. Human resources called labor intensiveness are the most dominant factor for healthcare service organization. Personal judgment about poor health service quality will affect patient visits. Avoiding such judgement, healthcare service organizations need to manage human resources well (Santi, 2016).

One of the issues related to human resources is turnover. Turnover intention is defined as a factor which mediates desires of stopping action in an organization (Dewi, Wulan and Fathoni, 2019). When an employee leaves his or her job, the organization needs to replace its employee. It is called as turnover. Several organizations stated that turnover is a problem which impacts the cost.

Besides, turnover causes disadvantages to organizations in several matters because they have to replace the old employees with the new ones (Kessler - Ladelsky, 2014). There are financial issues related to turnover (Waldman et al., 2004). Healthcare service organizations will spend some expenses for recruitment and training for new employees. Besides, turnover also results in non-financial expenses, such as productivity loss and decrease in service quality.

Saputro et al. (2016) stated that the high turnover intention will become a serious problem for the company and even make them frustrated, knowing the staff recruited have chosen jobs in other companies (Saputro, Fathoni and Minarsih, 2016). Moreover, Sartono et al. (2018) stated that humans are important resources in industries and organizations. Thus, managing human resources can be done by providing and maintaining the quality labor and its costs. Previous research showed that money loss due to decreasing productivity as stated in Cost of Reduced Productivity (CoRP) in healthcare facilities was 7 million up to 19 million dollars or more than $5 \%$ of the annual operational budget (Deane and Howard, 2004). An organization needs to make sure their human resources to avoid turnover (Sartono, Yulianeu and Hasiholan, 2018).

According to Lim et al. (2017), turnover could be differentiated into 2 types, such as Voluntary Turnover (VT) and Involuntary Turnover (IT). Voluntary turnover happens when employees resign from their job due to personal intention, such as better career opportunities in other organizations. Some other factors of voluntary turnover are job dissatisfaction, salary and benefit rate, supervision, and employee's personal reasons. Meanwhile, involuntary turnover occurs because the organization fires employees because of poor performance or violation of the organization rules.

Surabaya Surgical Hospital is one of the private hospitals in Surabaya, founded by surgeons who are members of Indonesian Surgeon Association (IKABI). Based on the Human Resource Department of Surabaya Surgical Hospital, the turnover rate at the hospital was quite high. This study is especially concerned about voluntary turnover at Surabaya Surgical Hospital. A competent employee may feel dissatisfied with the organization; thus, they seek for another job. High voluntary turnover rate indicates that several problems occur in the organization. It needs to grasp factors contributing to the turnover and develop strategies to solve it (Hilton, 2015). While, involuntary turnover is mostly caused by the poor employee performance, thus the organization decides to fire the employees. 


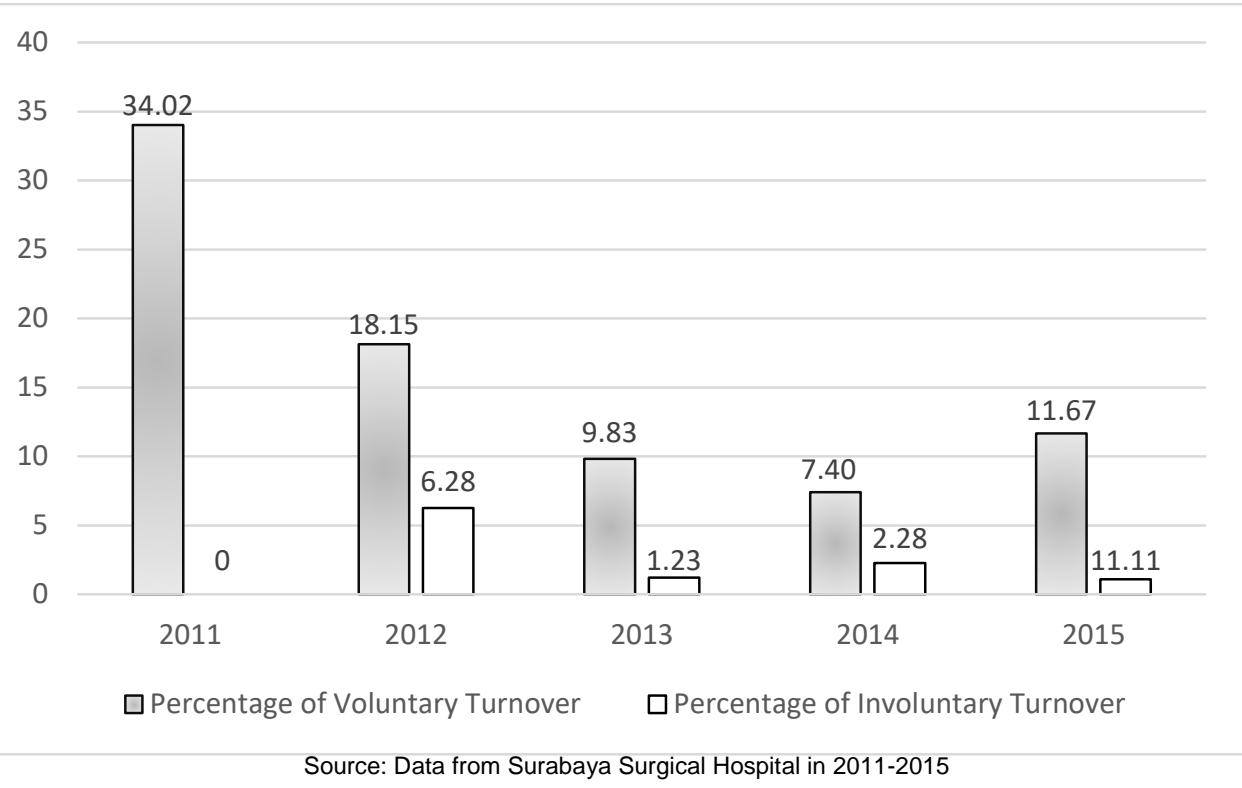

Figure 1. Employee Turnover Rate at Surgical Hospital Surabaya from 2011 to 2015.

Turnover is the final result of burnout syndrome. Burnout syndrome is defined as employees' negative behavior and feelings towards their work due to long exposure to an emotional stressor. Burnout syndrome consists of three different aspects, such as emotional exhaustion, depersonalization and personal accomplishment (Morgan, De Bruin and De Bruin, 2014).

Burnout syndrome affects not only people with burnout syndrome but also others who surround them. Klein et al. (2010) did research about a male surgeon who suffered from burnout syndrome. He tended to make several mistakes while working. Absenteeism is the most frequent impact of burnout syndrome (Dyrbye et al., 2019). Burnout syndrome also causes personal dysfunctions especially health problems. Burnout syndrome occurs to employees whose expectation about their work is not fulfilled, and thus it results in turnover intention.

Ribeiro et al. (2014) explained that health workers have risks of burnout syndrome for closely contact with patients at work. Figure 1 shows that the voluntary turnover rate at Surabaya Surgical Hospital tends to decrease from 2011 to 2014 but increases into more than 10\% in 2015. Employee turnover will be categorized as normal if its average is between 5 and $10 \%$ per year (Gillies, 1994). It will be considered high if the average is more than $10 \%$ per year. However, Surabaya Surgical Hospital has the standard of employee turnover rate at $7.5 \%$ in 2015 . Although this rate is lower than Gillies's, it can be considered problematic. Most previous studies examined the influence of burnout syndrome on turnover intention. This present study is worthy since it analysed how burnout syndrome influences turnover intention through organizational commitment as the intermediate variable. Besides, the pattern of turnover theory could me more clearly understood by adding an intermediate variable. The research objective was to determine burnout syndrome effect to turnover intention through organization commitment as an intermediate variable. Therefore, turnover process could be explained comprehensively. 


\section{[]JKI \\ JURNAL ADMINISTRAS
KESHATAN INDONESA}

METHOD

This study was observational with cross-sectional design because there was no intervention or experiment for respondents in collecting data. The sampling technique used was proportionate stratified random sampling. It was assumed that this study involved heterogeneous population, which consist of several stratum (Supriyanto and Djohan, 2011). This study was conducted at Surabaya Surgical Hospital from February to July 2016, while the data were collected on May 2016. It is a special type-B hospital which established by most surgeons specializing in IKABI (Indonesian Association of Surgeons) and provides surgical services.

The respondents were employees who have already worked at Surabaya Surgical Hospital for at least 6 months. These inclusion criteria were taken by considering the working period of a new employee with three-month orientation and three-month assessment. If the employee meets the criteria, he/she can be involved as respondent, if not he/she will be dismissed. Moreover, this study assumes that six-month working is enough for employees to experience burnout syndrome. The population of this study were 180 employees who have already worked at least 6 months. The sample size was calculated by Slovin formula with $\alpha=$ 0.05 . Out of 180 respondents, minimum sample size was 125 respondents. However, this study involved 126 people instead because the proportion of employees in each unit was also considered.

The study used Maslach Burnout Inventory (MBI) questionnaire as the instrument of burnout syndrome. It consisted of 22 statements which 7 statement items measured indicators of emotional exhaustion, 7 statement items measured depersonalization indicators,

and 8 statement items measured indicators of personal accomplishment (Sabbah et al., 2012). Each item could be answered in a 7point Likert scale ranging from "never" $(=0)$ to "daily" (=6). In addition, the organizational commitment of employees was measured using Meyer and Allen Model of Organization Commitment (Jaros, 2007). To measure the organizational commitment, there were 8 statement items on each type of commitments, such as affective commitment, continuance commitment and normative commitment. There were 24 items in total in the organizational commitment questionnaire with a 4-point Likert scale ranging from "strongly disagree" $(=1)$ to strongly agree $(=4)$. Data were collected through a questionnaire which consists of 3 statements about employee's desire to stay in the organization. This questionnaire has a 4-point Likert scale ranging from "strongly disagree" $(=1)$ to strongly agree $(=4)$.

To assess questionnaire validity and reliability, researchers conducting validity and reliability test at Mother and Child Hospital NUN Surabaya which had the same characteristics as Surabaya Surgical Hospital. It was a special type-B hospital. Data were collected by interview. The number of respondents involved in the validity and reliability test was 30 employees. All of statement items in the questionnaires had scores more than $R$ table $=0.361$. it could be concluded that the research instrument was valid. The Cronbach's alpha value was at 0.826 , meaning the questionnaire was reliable (Cronbach's alpha value $>0.06$ ).

The characteristics of respondents, i.e., age, gender, education level, and employment status were analysed using descriptive statistic. Data were analysed quantitatively as respondents' perception was measured using a scale. Multiple linier regression measured the respondents' perception by looking at $p<\alpha(0.05)$ to measure the effect of independent variable 
towards dependent variable. Furthermore, it also looked at $\beta$-value to determine the effect size and direction. The effect of variable independent was considered significant on the dependent variable if it has $\alpha<0.05$.

\section{RESULTS AND DISCUSSION}

In this section, it presents respondents' characteristics, such as gender, age, education level, employment status, and work period.

\section{Gender and Age}

Results showed the respondents were mostly female $(65.1 \%)$. Most of them were $26-35$ years old (62.7\%), categorized as early adult. Only few respondents (2.4\%) were categorized late adult (36-45 years old). The majority of respondents who were in the early adulthood appropriately can reflect employees' turnover intention. Early adulthood is a period where employees still have high productivity. When a job has no opportunities to increase the growth of employee, it can potentially hurt employee's future productivity because he or she feels has no opportunity for learning. In that period, employees easily can decide to turnover or leave the organization if they find a gap between expectation and organization regulations.

\section{Education Level}

In terms of education level, the respondents were mostly undergraduates $(89.7 \%)$. In summary, the majority of respondents were highly educated. Education level may influence people's decision-making process.

\section{Employment Status and Work Period}

Based on the employment status, most of the respondents were permanent employees $(95.2 \%)$, and only $4.8 \%$ were temporary contract employees. Most of respondents have worked for 3 up to 4 years $(40.5 \%)$, and the rest have worked for more than five years. These data were assumed to match with conditions where burnout syndrome may occur after long exposure to tasks.

Burnout syndrome is negative feeling and attitude of employees towards their job as a response to a stressor which can come in a long period of time. Burnout syndrome may be in forms of emotional exhaustion, depersonalization and personal accomplishment. Emotional exhaustion is a psychological condition in which people lack enthusiasm for work. Meanwhile, depersonalization is a psychological state in which cynicism or negative reaction and ignorance towards works environment occur. The last is decreasing personal accomplishment, a psychological state in which the level of productivity declines

Based on Table 1 and 2, the measurement of emotional exhaustion shows a mean score of 2.18 . It shows that the employees had low emotional exhaustion during work. While, they obtained a mean score of 1.23 , explaining moderate depersonalization during work. In the other aspect, they got a mean score of 5.01 for personal accomplishment, portraying high category of personal accomplishment. These findings are similar to the research conducted by Enginyurt et al. (2016). Both studies found the burnout syndrome level among physicians and health workers were low in terms of emotional exhaustion and depersonalization, but high in terms of personal accomplishment. Feeling towards personal accomplishment among health workers can improve if employees' perception of commitment, especially affective commitment, to the organization gets better. 
Table 1. Burnout Syndrome Measurement Based on Respondents' Perception at Surabaya Surgical Hospital.

\begin{tabular}{lll}
\hline Variables & Mean & Average \\
\hline Emotional Exhaustion & 3.04 \\
\hline I am emotionally exhausted due to my work & 3.52 \\
\hline I require a great deal of efforts to work with people all day long & 2.91 \\
\hline My work stressed me & 1.52 & \multirow{2}{*}{2.18} \\
\hline My work frustrated me & 2.62 \\
\hline I work too hard in fulfilling my job & 1.30 \\
\hline I am stressed too much while working in direct contact with people & 1.10 \\
\hline I feel like I am at the end of my rope & \\
\hline Depersonalization & 0.42 \\
\hline I treat certain patients impersonally as if they were objects & 0.98 \\
\hline In the morning I feel tired to get up and face up to another day at work & 2.97 \\
\hline Patients make me feel to responsible for some of their matters & 1.61 \\
\hline I feel a little patience at the end of workday & 0.65 \\
\hline I do not care about what happens to some patients & 1.23 \\
\hline I become more insensitive to people & 0.10 \\
\hline I am afraid that this job makes me unaware & \\
\hline Personal Accomplishment & 4.61 \\
\hline I accomplished many valuable things in my work & 5.26 \\
\hline I feel very spirited & 4.99 \\
\hline I can easily figure out the patients' feeling & 4.56 \\
\hline I can effectively treat patients' problems & 5.02 \\
\hline I can handle emotional problems very calmly & 5.13 \\
\hline I feel to have a positive influence on people because of this job & 5.21 \\
\hline I easily can create a relaxing atmosphere with patients & 5.30 \\
\hline I feel refreshed when I am close with my patients &
\end{tabular}

Table 2. Results of Burnout Syndrome Categorization.

\begin{tabular}{lll}
\hline \multicolumn{1}{c}{ Variables } & \multicolumn{1}{c}{ Mean Scores } & \multicolumn{1}{c}{ Categories } \\
\hline Emotional Exhaustion & $\leq 2.43$ & Low Emotional Exhaustion \\
\cline { 2 - 3 } & $2.44-\leq 4.14$ & Moderate Emotional Exhaustion \\
\cline { 2 - 3 } & $\geq 4.15$ & High Emotional Exhaustion \\
\hline Depersonalization & $\leq 0.71$ & Low Depersonalization \\
\cline { 2 - 3 } & $0.72-\leq 1.57$ & Moderate Depersonalization \\
\cline { 2 - 3 } & $\geq 1.58$ & High Depersonalization \\
\hline Personal Accomplishment & $\leq 4.13$ & Low Personal Accomplishment \\
\cline { 2 - 3 } & $4.14-\leq 4.88$ & Moderate Personal Accomplishment \\
\cline { 2 - 3 } & $\geq 4.89$ & High Personal Accomplishment \\
\hline Burnout Syndrome & $\leq 2.67$ & Low Burnout Syndrome \\
\cline { 2 - 3 } & $\geq 2.68-3.28$ & Moderate Burnout Syndrome \\
\cline { 2 - 3 } & $\geq 3.29$ & High Burnout Syndrome \\
\hline
\end{tabular}


Organizational commitment is a trust for accepting organizational goals and staying in the organization. It is high desire and belief to stay as a member and to accept the organizational values and goals. In other words, it is a behaviour that shows employees' loyalty to the organization as well as describes on-going process of expressing attention to the organization success. Committed employees usually have a good attendance record, show loyalty and have a low turnover rate. Such employees may have good commitment and loyalty because they perceive they are involved in the organization activities (Wibowo, 2014).

Enginyurt et. al. (2016) stated that three subdimensions which best describe organizational commitment are affective, continuance and normative commitment. First, affective commitment is a feeling to stay involved in the organization due to similar self-purposes to the organization's terms. The strong affective committed employees work voluntarily and passionately since it is their own choice to work for the organization. Second, employee will remain in the organization due to benefits given by the organization, it is called continuance commitment. Employees particularly want to stay in the current organisation if the cost of termination is considered high. Continuance commitment mostly comes up from individuals' investments in the organisation, such as long-term effort or financial ties, and the absence of other business alternatives. Employees who have a sense of liability for the organization might have normative commitment to stay in. The concept of continuance commitment has been widely studied in terms of emotional bond between an employer and employee so-called as psychological contracts. The results of organizational commitments were as follow (Table 3).

Results also showed the mean scores of affective commitments, continuance commitment, and normative commitment are 2.75, 2.54, and 2.66 respectively. The measurement of affective, continuance, and normative commitment is categorized into 4 ranges; 1 ) Mean score 1 - $\leq 1.75$ (very low); 2) Mean score $\geq 1.76$ - $\leq 2.50$ (low); 3 ) Mean score $\geq$ 2.51 - $\leq 3.75$ (high); and 4) Mean score $\geq$ $3.76-4$ (very high). Among three types of organizational commitment, affective commitment has the highest mean score of 2.75. Shurbagi (2014) asserted employees who have affective commitment are going to be more dedicated and have willingness to stay in the organization. Management team can use management by objective to develop a better commitment and engagement to align employee's selfpurposes with organization's goals. Moreover, this present study discovered that the employees had high continuance and normative commitment since the mean score exceeds 2.5. To sum up, the organizational commitment of employees at Surabaya Surgical Hospital is in high category (means cores 2.65).

Table 3. Organizational Commitment Measurement Based on Respondents' Perception at Surabaya Surgical Hospital.

\begin{tabular}{lcc}
\hline \multicolumn{1}{c}{ Type of Organizational Commitment } & $\begin{array}{c}\text { Mean } \\
\text { Scores }\end{array}$ & Mean Scores \\
\cline { 1 - 2 } Affective commitments & 2.75 & \multirow{2}{*}{2.65} \\
\hline Continuance commitment & 2.54 & \\
\hline Normative commitment & 2.66 & \\
\hline
\end{tabular}




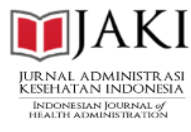

In spite of this fact, there were some indicators that the employees did not have high organizational commitment. The affective commitment indicators showed that most of employees are not very happy to work in the organization forever (53.2\%). They also think that they can out to work in another organization (46\%). In continuance commitment indicators, the employees will not be disrupted if leaving the organization at that time (61.1\%). Moreover, there were no serious consequences for leaving the organization (56.3\%), and one of the major reasons is that turnover will not require considerable personal sacrifice $(45.2 \%)$. In terms of normative commitment indicators, the employees thought moving from organization to another organization is not that unethical $(64.3 \%)$. If they get another offer for a better job elsewhere, they may think it is right to leave their organization (63.5\%).

Moreover, the result of employee's turnover showed the mean score 2.39. If the mean score $>2.5$ showed that most employees in Surabaya Surgical Hospital have high turnover intention. The effect of burnout syndrome on turnover intention using organizational commitment as the intermediate variable was explained in Table 3. The variables were tested by using multiple linear regression.

Table 4 explicates that burnout syndrome significantly affects the organizational commitment of employees at Surabaya Surgical Hospital $(p=0.018<$ $\alpha=0.05$ ). Burnout syndrome contributes to organizational commitment with $\beta$ value equal to 0.211 . It suggests that the burnout

syndrome rate at Surabaya Surgical Hospital is $21.1 \%$, influenced by the variations of burnout syndrome variables. The remaining is influenced by other factors beyond burnout syndrome. The $\beta$-value is negative. It suggests the higher burnout syndrome is, the lower the organizational commitment is.

This result is similar to what Enginyurt et. al. (2016) have found in their study. A cross-sectional survey conducted to 43 physicians, 123 nurses, 134 technicians, and 181 other caregivers working at Ordu University Education and Research Hospital under Ministry of Health. Data were also collected using the Organizational Commitment Questionnaire and Maslach Burnout Inventory (MBI). They found burnout syndrome was statistically significant to organizational commitment. Organizational commitment which consists of affective commitment, continuance commitment and normative commitment has potential indicators for the onset of burnout syndrome (emotional exhaustion, depersonalization and personal accomplishment). Moreover, these findings higlight that affective commitment is considered as one of the dominant factors causing burnout syndrome among healthcare professionals.

Moreover, Lin et. al. (2011) conducted a study which confirmed the relationship between three aspects (job stress, job burnout, and job satisfaction) and organizational commitment) among Taiwanese medical radiologists. The participants of this study were 310 medical radiologists who work in academic medical

Table 4. Effect of Burnout Syndrome and Organizational Commitment on Turnover Intention.

\begin{tabular}{lllc}
\hline \multicolumn{1}{c}{ Independent Variables } & \multicolumn{1}{c}{ Dependent Variables } & Sig & Beta \\
\hline Burnout Syndrome & Organizational Commitment & 0.018 & -0.211 \\
\hline $\begin{array}{l}\text { Organizational } \\
\text { Commitment }\end{array}$ & Turnover Intention & 0.000 & -0.563 \\
\hline Burnout Syndrome & Turnover Intention & 0.610 & 0.039 \\
\hline
\end{tabular}


centers, metropolitan hospitals, or local community hospitals. The SEM confirmatory factor analysis was in use to test the hypotheses. Based on the result, job burnout had a significant but negative correlation to organizational commitment.

Another finding of this present study is that burnout syndrome did not significantly affect turnover intention $(p=0.610>\alpha=0.05)$. This is similar to the results of survey conducted by (Narainsamy and Westhuizen, 2013) to investigate the quality of work-related wellbeing among medical laboratory employees. The objective of this study was to measure the job satisfaction, occupational stress, work engagement, and burnout. It was a cross-sectional survey in which 202 medical laboratory staffs from two prominent private laboratories participated. Like other studies, Maslach Burnout Inventory was used to measure burnout. This study showed that burnout and occupational stress had a negative correlation with job welfare. However, this study did not identify the correlation of burnout with turnover or turnover intention.

The researchers utilized multiple linier regression to test burnout simultaneously with organizational commitment. They discovered organizational commitment significantly influenced turnover intention, but burnout did not significantly influence turnover intention. It may be due to the fact that the effect of organizational commitment was bigger than that of burnout towards turnover intention. Thus, burnout did not significantly affect turnover intention.

The analysis of burnout showed that the employees had low emotional exhaustion (Mean $=2.18)$, low depersonalization (Mean=1.23), and high personal accomplishment (Mean= 5.01). Whereas, the employees had a high turnover intention (Mean= 2.39). Even though they had a low burnout rate, the turnover intention was high. One of the confounding variables to this condition is career opportunity.

Employees' perception affects turnover intention. If so, turnover may lead people to move to other companies. If labour market conditions deteriorate, employees may decide to remain in the organization. Conversely, when opportunity for employment are large, the turnover intention rate increases (Santi, 2016).

Career opportunities are not only related to compensation. Career growth opportunity also becomes an external factor that causes turnover intention. Most of the employees at Surabaya Surgical Hospital were aged $21-30$ years $(59.5 \%)$, meaning that they still have time and desire for career advancement.

Career is a continuity of job experiences in a person's lifetime. The carer growth opportunity refers to an ongoing process, and application of skills, and an ongoing process of planning and directing action towards personal work and life goals. Career opportunity can be defined as a sense where employee's current position suits with their career objectives and concerns in the organization. The concept of organizational support for programs and opportunities to support employee's development is different from the concept of perceived career opportunity. When employees' interests suit with their career concerns and objectives, employees will perceive that they obtain a career growth.

Many researchers have noted that due to diverse reasons (e.g., technological growth, developed knowledge bases and the emergence of global competition), the career's trait has thrived fast. In spite of that, it might be related to a shorter period of retention in an organization. For example, instant training and development programs to the future of employability could motivate core employees in organization. 


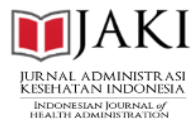

Toh and Denisi (2003) mentioned that the different payment between two groups also leads to frustrations and discouragement. In addition, the nature of international staffing can negatively affect local employees' career visions and organizational identifications. Local employees are those whose usual place of residence is within the local area. Local employees would feel that their opportunities taken away. It is related to turnover believed as the result of unfulfilled employee's career and chances, while the organization that promotes career growth opportunity may have a high retention rate. In summary, turnover intention is related to perceived career growth opportunity.

Another result of this present study showed that organizational commitment significantly influences turnover intention $(p=0.000<\alpha=0.05)$. Organizational commitment contributes to turnover intention with $\beta$-value at 0.563 . It showed that turnover intention rate at Surabaya Surgical Hospital was $56.3 \%$ due to variations inorganizational commitment variable. While, the remaining of $43.7 \%$ was affected by other factors beyond organizational commitment. The $\beta$-value was negative, depicting that the lower organizational commitment is, the higher turnover intention is. In conclusion, burnout syndrome can cause turnover intention when organizational commitment becomes the intermediate variable. However, this study found burnout syndrome did not significantly affect turnover intention.

Organizational commitment is the level to which employees believe and accept organizational goals, so the want to stay in organization. Sartono, Yulianeu and Hasiholan (2018) stated that organizational commitment is reflected by individual to match his self-purposes and organization goals. Organizational commitment affects decision-making whether to stay as a member or leave for a new job. Kharismawati and Dewi (2016) also argued

that organizational commitment is compliance to remain in an organization.

Avanzi et. al. (2014) used a social identity theory in identifying its association with organizational commitment. This study showed that employees' organizational commitment at Surabaya Surgical Hospital affects turnover intention. Turnover intention can be defined as individual's desire to quit from organization (Azanza et. al., 2015). Khan (2015) further elaborated that turnover intention is the final cognitive decision-making process before an employee decides to leave a job. Among three variations of organizational commitment, they are all psychological states as regard to the relationship between the employees and the organization and implications for turnover intention in the organization. Other research also stated that those types of organizational commitment had a negative correlation with turnover intention. Mathieu et. al. (2015) explained only organizational commitment significantly affected turnover intention.

Moreover, the meta-analysis research concluded that job satisfaction could not predicted turnover better than organizational commitment (Griffeth, Hom and Gaertner in Mathieu et al., 2015). Some researchers explained that organizational commitment developed from job satisfaction and mediates the effect of job satisfaction on turnover intention. Organizational commitment had a significant effect towards turnover intention and its effect was negative (Alfresia, 2016). Job burnout is mentioned as exhaustion of both mental and physical. It is a long-term stress response to emotional and interpersonal stressors at work, which encompass emotional exhaustion, depersonalization, and reduced personal accomplishment (Peng et. al., 2016). Emotional exhaustion is an extreme emotional fatigue resulting in the lack of enthusiasm about works. When employees 
feel emotionally drained, they will impulsively provide services. They still feel exhausted and less enthusiastic even though they have had enough rest. When employees suffer from burnout syndrome, they will avoid to work in contact with people.

Depersonalization refers to the intentional effort to keep distance from individual and their work, as well as to exhibit passive, apathetic, cynical attitudes and sensitive towards others, such as treating patients badly. When reduced personal accomplishment occurred, it showed the low sense of self-respect and even more in low work evaluation, inability to experience comfort, satisfaction, and a sense of accomplishment. Xiaoming et. al. (2014) stated that reduced personal accomplishment can be in forms of poor self-evaluation results, low interpersonal relationships, loss of enthusiasm, decreased productivity and lack of adaptability.

In addition, Xiaoming et. al. (2014) used cross sectional design with Maslach Burnout Inventory (MBI) as the research instrument. Findings showed that burnout had a negative correlation with job stress, but burnout syndrome had no correlation with turnover intention. These results were similar to research conducted by Ford et al. (2019) which involved 1.500 teachers from 73 schools in a large, high-poverty, and urban Midwestern district school. The study presented a direct relationship between burnout and turnover intention through organizational commitment. Burnout and organizational commitment were the strongest direct predictor (Ford et. al., 2019). This supports this present study which organization commitment has a direct effect towards turnover intention from the Hospital and their profession.

Nevertheless, this present study provides dissimilar results to the research stating burnout syndrome affects turnover intention. The previous study done by
Ohue, Moriyama and Nakaya, (2011) explained that nurses' turnover intention had a positive relation to emotional exhaustion. Intention to stay had a negative relation to emotional exhaustion and depersonalization, but positively related to personal accomplishment. Therefore, Ohue, Moriyama and Nakaya (2011) concluded that employees who try to leave their current jobs might suffer from burnout syndrome and should undergo burnout prevention program for reducing the turnover rate. Burnout can affect turnover intention when organizational commitment decreases. Wang, Hall and Rahimi (2015) stated that there was a positive relationship between burnout syndrome and turnover intention. It is worth noting that few (if any) studies have distinguish between turnover intention from the organization and profession as this present study has discussed so far.

\section{CONCLUSION}

The employees at Surabaya Surgical Hospital had low emotional exhaustion rate, moderate depersonalization rate and high personal accomplishment. However, some indicators of emotional exhaustion and depersonalization showed that employees need great efforts to work with other people and to be responsible for patients' problems. The assessment of organizational commitment depicted that the employees had high affective, continuance and normative commitment. However, the employees did not have high assessment in all indicators of organizational commitment.

In terms of affective commitment, some indicators mention that the employees are not very happy to spend the rest of their career in the organization, thus they might prefer another organization. Meanwhile, the indicators of continuance commitment point out that most of the employees take it easy to leave for another 
job because there are no serious consequences and personal sacrifice. The employees also did not consider turnovers unethical for a better job. This condition, in summary, describes the indicators of normative commitment that they experience at work. To summarize this present study, burnout syndrome influenced turnover intention as organizational commitment decreased. However, burnout syndrome did not significantly influence turnover intention. The hospital managers need to minimize employee's turnover intention by decreasing burnout syndrome and increasing organizational commitment, for example, using a better reward system.

\section{CONFLICT OF INTEREST}

The authors state that there is no conflict of interest for this article.

\section{REFERENCES}

Alfresia, V. P. (2016) Pengaruh Kepuasan Kerja dan Komitmen Organisasi terhadap Turnover Intention (Studi pada PT. Kajima Indonesia). Universitas Negeri Yogyakarta.

Avanzi, L. et al. (2014) 'Staying or leaving: A combined social identity and social exchange approach to predicting employee turnover intentions.', International Journal of Productivity and Performance Management, 63(3), pp. 272-289.

Azanza, G. et al. (2015) 'The effects of authentic leadership on turnover intention.', Leadership \& Organization Development Journal, 36(8), pp. 955-971.

Deane, J. and Howard, L. (2004) 'Journals Books My Workspace Primal Pictures The Shocking Cost of Turnover in Health Care', Health care management review, 29(1), pp. 1-7. Available at: http://www.ncbi.nlm.nih.gov/pubmed/ 14992479.

Dewi, A. F., Wulan, H. S. and Fathoni, A. (2019) 'Organizational commitment, organizational climate, and job security towards turnover intention and job satisfaction as mediating variables at PT. Senat Garment', Journal of Management, 5(5), pp. 18. doi: 10.7129/jject.7.165.

Dyrbye, L. N. et al. (2019) 'A crosssectional study exploring the relationship between burnout, absenteeism, and job performance among American nurses', $B M C$ Nursing. BMC Nursing, 18(1), pp. 18. doi: 10.1186/s12912-019-0382-7.

Enginyurt, O. et al. (2016) 'Relationship between organisational commitment and burnout syndrome: A canonical correlation approach', Australian Health Review, 40(2), pp. 181-187. doi: $10.1071 / \mathrm{AH} 14177$.

Ford, T. G. et al. (2019) 'The effects of leader support for teacher psychological needs on teacher burnout, commitment, and intent to leave', Journal of Educational Administration, 57(6), pp. 615-634. doi: 10.1108/JEA-09-2018-0185.

Gillies D. A. (1994) 'Manajemen Keperawatan: Suatu Pendekatan Sistem 3rd Edition', in. W.B Saunder Company.

Hilton, T. L. (2015) Effect of Burnout and Organizational Commitment on the Turnover Intention of Clinical Laboratory Employees in Florida. Walden University, United States.

Jaros, S. (2007) 'Meyer and Allen Model of Organizational Commitment: Measurement Issues', in. India: the Icfai University Press, pp. 7-26.

Kessler - Ladelsky, L. (2014) 'The Effect of Job Satisfaction on IT Employees Turnover Intention in Israel', Annals of the University of Oradea: Economic Science, 23(1), pp. 10281038.

Khan, S. L. (2015) Transformational leadership and turnover intention: the mediating effects of trust and performance. Doctoral Dissertation. Bangkok University.

Kharismawati, D. A. P. and Dewi, I. G. A. M. (2016) 'Pengaruh Komitmen Organisasional, Dukungan Sosial, Dan Iklim Etika Terhadap Turnover Intention', E-Jurnal Manajemen 
Universitas Udayana, 5(2), pp. 13681398.

Klein, J. et al. (2010) 'Burnout and perceived quality of care among German clinicians in surgery', Journal for Quality in Health Care, 22(6), pp. 525-530.

Lim et al. (2017) 'The impact of transformational leadership on turnover intention: The mediating role of affective commitment', Journal of Applied Structural Equation Modeling, 11(3), pp. 27-41.

Mathieu, C. et al. (2015) 'The role of supervisory behavior, job satisfaction and organizational commitment on employee turnover', Journal of Management and Organization, 22(1), pp. 113-129. doi: 10.1017/jmo.2015.25.

Morgan, B., De Bruin, G. P. and De Bruin, K. (2014) 'Operationalizing burnout in the Maslach Burnout InventoryStudent Survey: Personal efficacy versus personal inefficacy', South African Journal of Psychology, 44(2), pp. 216-227. doi: $10.1177 / 0081246314528834$.

Narainsamy, K. and Westhuizen, S. Van Der (2013) 'Work related well-being: Burnout, work engagement, occupational stress and job satisfaction within a medical laboratory setting', Journal of Psychology in Africa, 23(3), pp. 467474. doi: 10.1080/14330237.2013.10820653.

Ohue, T., Moriyama, M. and Nakaya, T. (2011) 'Examination of a cognitive model of stress, burnout, and intention to resign for Japanese nurses', Japan Journal of Nursing Science, 8(1), pp. 76-86. doi: 10.1111/j.1742-7924.2010.00161.x.

Peng, J. et al. (2016) 'How can core selfevaluations influence job burnout? the key roles of organizational commitment and job satisfaction', Journal of Health Psychology, 21(1), pp. 50-59. doi: $10.1177 / 1359105314521478$.

Sabbah, I. et al. (2012) 'Burnout among Lebanese nurses: Psychometric properties of the Maslach Burnout Inventory-Human Services Survey

(MBI-HSS)', Health, 04(09), pp. 644652. doi: 10.4236/health.2012.49101.

Santi, M. W. (2016) Pengaruh Faktor Burnout Syndrome dan Faktor Lingkungan terhadap Turnover Intention Karyawan. Masters Thesis. Universitas Airlangga.

Saputro, H., Fathoni, A. and Minarsih, M. M. (2016) 'Pengaruh Kepuasan Kerja, Ketidakamanan Kerja \& Komitmen Organisasi Terhadap Intensi Pindah Kerja (Turnover Intention) Studi Kasus pada Distribution Center PT. Sumber Alfaria Trijaya Cabang Rembang, Jawa Tengah', Journal of Management, 2(2), pp. 1-14.

Sartono, M., Yulianeu, Y. and Hasiholan, L. B. (2018) 'Pengaruh Kompensasi, Motivasi Kerja dan Komitmen Organisasi Terhadap Turnover Intention', Journal of Management, 4(4), pp. 1-13.

Shurbagi, A. M. A. (2014) 'The relationship between transformational leadership style job satisfaction and the effect of organizational commitment', International Business Research, 7(11), pp. 126-138.

Supriyanto, S. and Djohan, A. J. (2011) Metodologi Riset Bisnis dan Kesehatan. Banjarmasin: Grafika Wangi Kalimantan.

Toh, S. M. and Denisi, A. S. (2003) 'Host country national reactions to expatriate pay policies: A model and implications', Academy of Management Review, 28(4), pp. 606-621. doi: 10.5465/AMR.2003.10899387.

Waldman, J. D. et al. (2004) 'Journals Books My Workspace Primal Pictures The Shocking Cost of Turnover in Health Care', Health care management review, 29(1), pp. 1-7. Available at: http://www.ncbi.nlm.nih.gov/pubmed/ 14992479.

Wang, H., Hall, N. and Rahimi, S. (2015) 'Self-efficacy and causal attributions in teachers: effects on burnout, job satisfaction, illness, and quitting intentions', Teaching and Teacher Education, 47, pp. 120-130. 
Wibowo (2014) Manajemen Kinerja Edisi ke 4. Jakarta: Rajawali Pers.

Xiaoming, Y. et al. (2014) 'Effects of workload on burnout and turnover intention of medical staff: A study', Studies on Ethno-Medicine, 8(3), pp. 229-237.

doi: 